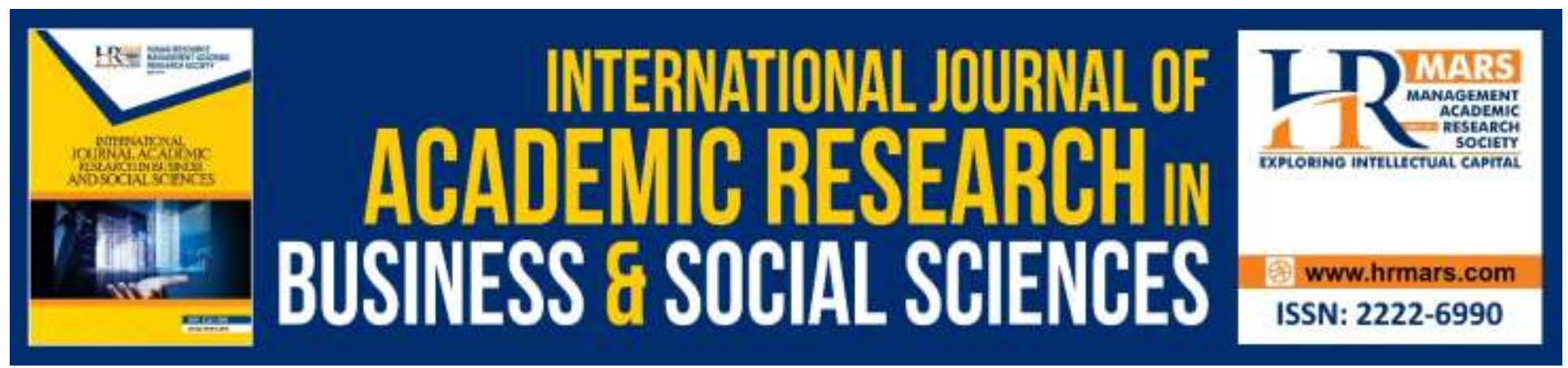

\title{
To Investigate the Relationship between Job Demand, Job Resources and Job Performance: An Examination of Mediating Variables
}

Anila Fatima, Abeera Matloob, Muhammad Afaq Hussain Khan

To Link this Article: http://dx.doi.org/10.6007/IJARBSS/v9-i11/6539 DOI: 10.6007/IJARBSS/v9-i11/6539

Received: 10 October 2019, Revised: 25 October 2019, Accepted: 01 November 2019

Published Online: 15 November 2019

In-Text Citation: (Fatima, Matloob \& Khan, 2019)

To Cite this Article: Fatima, A., Matloob, A., Khan, M. A.H. (2019). To Investigate the Relationship between Job Demand, Job Resources and Job Performance: An Examination of Mediating Variables. International Journal of Academic Research in Business and Social Sciences, 9(11), 159-175.

Copyright: (C) 2019 The Author(s)

Published by Human Resource Management Academic Research Society (www.hrmars.com)

This article is published under the Creative Commons Attribution (CC BY 4.0) license. Anyone may reproduce, distribute, translate and create derivative works of this article (for both commercial and non-commercial purposes), subject to full attribution to the original publication and authors. The full terms of this license may be seen at: http://creativecommons.org/licences/by/4.0/legalcode

Vol. 9, No. 11, 2019, Pg. 159 - 175

Full Terms \& Conditions of access and use can be found at http://hrmars.com/index.php/pages/detail/publication-ethics 


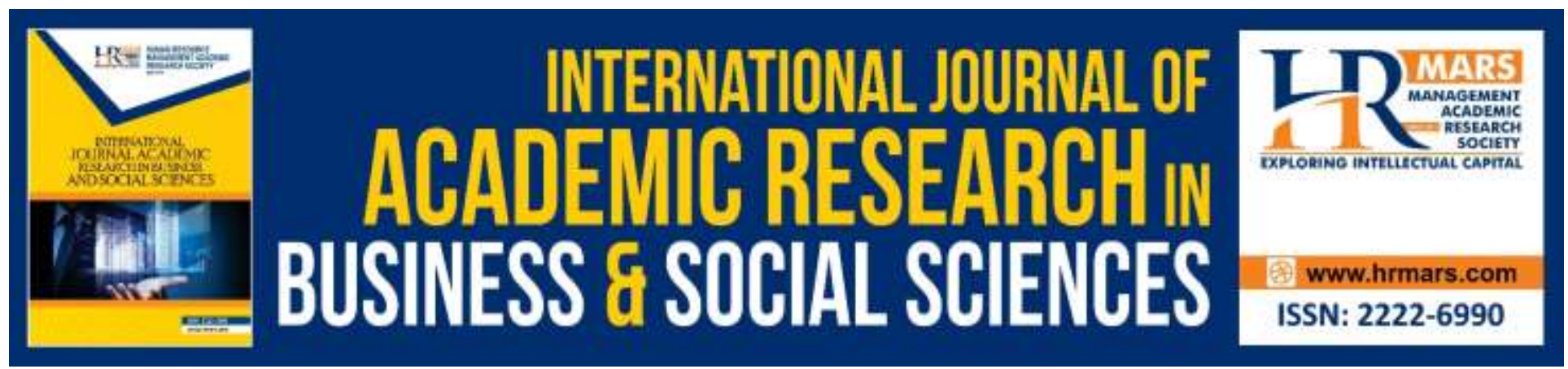

\title{
To Investigate the Relationship between Job Demand, Job Resources and Job Performance: An Examination of Mediating Variables
}

\author{
Anila Fatima, Abeera Matloob, Muhammad Afaq Hussain Khan \\ Lyallpur Business School, Government College University Faisalabad, Pakistan \\ Email: ridaanila@yahoo.com, abeeera786@gmail.com, m.afaq1414@gmail.com
}

\begin{abstract}
The goal of this study is to analyze and explore the relationship between job Demand, job Resources and job Performance through mediating variables work engagement and job security The data were collected from services sector in Pakistan form different sector through simple random sampling. The sample size was consisted of 320 respondents. The instrument used was structured questionnaires. SPSS 23 was used to assess the direct and indirect relationship between variables. Study concludes that there is positive direct link between job resources, job demand and job performance. While job security and work engagement positively mediated the relation between job demand, job performance and job resources. The findings of this study can be helpful for employers in making betterment in their performance. However, it shall also support as a basis of reference for future research and investigation.
\end{abstract}

Keywords: Job Demand, Job Resource, Job Performance, Work Engagement, Job Security

\section{Introduction}

Employment efficiency is the key to the achievement and results of the organization. The variable is a single amount. It evaluates whether or not an individual works well in the organization. The work's job does describe mandatory comportments; contextual comportments are comportments which do not meet the particular elements of the work's function. Organizations need staff members to meet growing work requirements and utilize their attempts to perform well in an organization to remain and thrive under pressures of unclear financial circumstances and rising global rivalry. The employees feel more stressful, however, and have strengthened their output. The poor results organization has had a poor effect, while the funds for work relate to the physical, psychological, cultural and organizational elements of the job which can be effective in attaining the job objectives, reducing the employment requirements and stimulating personal growth and development. The results of this study are not yet fully realized. 
The demands for jobs relate to the physical, psychological, social and/or organic aspect of the work that demands unrelenting physical and/or psychological energy and are associated with certain costs (Rothmann \& Jordaan, 2006). The JD-R model showed that the involvement in working is expected mainly by employment assets when job requirements are high. Job requirement was recognized as one of the most prevalent sources of job pressure. Study as mentioned (Braine \& Roodt, 2011). Under the explaining of the JD-R template, job requirements expect emotions of weariness, as well as the absence of funds leading to disengagement in employment (Demerouti, Bakker, Nachreiner, \& Schaufeli, 2001). (Xanthopoulou et al., 2007) thought that the JD-R system of work participation autonomously or jointly forecasts the participation in work. When demand for jobs is large, employment and staff funds have a beneficial effect on commitment and a beneficial effect on job performance. As such, committed, successful staff can generate their own funds that will promote commitment over moment again (Xanthopoulou et al., 2007). Work involvement is described as a favorable working state, since it has been shown to develop well-being and results for employees as a significant building in the fields of applied psychology and management sciences (Saks, 2006; Voorde, Veld, \& Veldhoven, 2016).

Until now, the relationship among job requirement and job performance has produced contradictory results with empirical studies finding positive, negative, and curvilinear and no linkages. The boundary words and their intermediate partnership may clarify these contradictory results. In order to tackle this issue, we would look beyond stress theories to the perspective of social exchange (Blau, 1964). Employee-employer relations involve contributions by employees in exchange for corporate incentives (Rousseau, 1990; Shore et al., 2004). Employees are often forced to meet extremely difficult job and/or overtime requests. Which opportunities do employers offer to reciprocate and maintain the partnership between employs? They contend that the long-term security of employees (Shaw, Dineen, Fang, \& Vellella, 2009) is critical.

There is increasing concern in the job involvement and there is a need to understand its history more and greater. Factors examined as priorities for work involvement, e.g. job autonomy, habits of self-regulation and character characteristics (Woods \& Sofat, 2013). "Strength, commitment and absorption characterize positive mental states" (Schaufeli, Salanova, González-Romá, \& Bakker, 2002). "Vigor," which refers to the extreme energy levels during the job, is the primary dimension of the commitment. Dedication relates to strong job participation and involves emotions of motivation, fulfillment, concern and importance. The ultimate aspect is described as "intake," so that moment comes to move quickly and that you will find it increasingly hard to distinguish yourself from job. In brief, committed staff operates tough, are enthusiastic and fully involved in their job, and if the commitment to job is strong there will be strong results (Bakker \& Demerouti, 2008).

In addition, staff fulfills high job challenges / demand and operate over period on a regular basis. In this scenario, job security balances the relationship between worker and boss sometimes because of work overload and stress and do not concentrate on their jobs. Security in the present operating setting is the principal cause of employee motivation. The individual with elevated occupational safety is more inclined to be good in the organization during elevated work demands and challenges and if the safety at employment is small, the relationship with the 
employer is uneven and the output is poor. The research is used as mediator between dependent and dependent variable job security and job involvement. In this research, we learn how the connection between work supply, jobs and job performance is strongly linked to work safety and the commitment to practice.

\section{Study Objectives}

$>$ Find out the relationship between job resources, job demands, job security and work engagement of employees.

$>$ To find out whether job security and work engagement helps to improve the job performance.

$>$ To analyze the how job performance is increase and decrease by the job demand and job resources.

\section{Literature Review}

Jobs, such as quick, difficult or large-scale working requirements in particular, the attitude and conduct of employees are to be compromised (Spector \& Jex, 1998). High labor needs for physiological issues or psychological cost have been determined, contributing to decreased efficiency. Simultaneously, it difficulties job Applications can encourage personal growth and development; possibly increase people's motive and achievement (Zhang, Lepine, Buckman, \& Wei, 2014). In reality, the findings between job requirements and performance are blended to date. Some surveys discovered that requirements for jobs and work efficiency have negative relationships, with others that have discovered no important relationships (Glaser, Tatum, Nebeker, Sorenson, \& Aiello, 1999). In working stress literature, empirical assistance in the reversed $U$-form is very restricted in the relationships between job demand and efficiency (Rosen, Chang, Djurdjevic, \& Eatough, 2010).

The relation between work requirements and results has been shown by witnesses to be difficult and limiting circumstances should be taken as moderating variables. The assessment of the research reveals the broad variety of confidence for working demands (i.e. workload), which explains the significant variety in terms of the total job results (Fried, Shirom, Gilboa, \& Cooper, 2008). Labor safety was the only information importer of this variation and examined if job safety could have a beneficial or bad impact on the connection between supply for employment and achievement. Our survey looked at the positive mediating effects of job security on the association between work and performance applications and the interaction of three working routes, job safety and traditional job performance. Based on the concept of cultural return, it adds to the current literature in various respects. As a vital motivation, we recognized job safety and examined its mediating impact on the connection between work and achievement apps. This includes prior research that used the views of stress theorists in particular (Rosen et al., 2010). Our findings could also illustrate the incompatible findings in the work-relate literature (Johnson et al., 2005), as safety at work is the most relevant workplace today, taking staff into account (W. Wang, Arora, Livescu, \& Bilmes, 2015). Job security relates to the perceptions of an employee about the stabilization and durability of the work of an organization (Kraimer, Wayne, Liden, \& Sparrowe, 2005). Despite drastic workforce modifications, long-term job security continues an 
ideal solution for many staff (Coyle-Shapiro \& Shore, 2007). Employee safety perceived in an organization may vary, although job safety is the outcome of organizational practices (Kraimer et al., 2005). When workers satisfy the demands of their staff and create them feel safe, fair distribution between workers and staff is created $(\mathrm{Ng}, 2015)$. An employee-employee transfer is a type of cultural exchange that represents an employee's subjective faith that they must provide their parents ' services and what incentives are required of their employers in return (Ahammad, Tarba, Liu, \& Glaister, 2016).

It is regarded as an employee's duty (also called "input") to fulfill requirements for difficult work, such like work difficult, operating overtime, and dealing with overwork (Rhoades, Eisenberger, \& Armeli, 2001). In exchange, long-term job security is regarded as one of the commitments of workers also known as "inducements" (Anis, Nasir, \& Safwan, 2011). Therefore, staff thinks that their workers have met their commitments when they encounter job safety. Employees are encouraged to submit themselves to good results in the interests of reciprocity (Kuo, Ho, Wu, \& Lin, 2010). In comparison, when presumed job safety is small, the connection between staff and workers (Keim, Landis, Pierce, \& Earnest, 2014) can be regarded as an injustice because staff feel their workers have not fulfilled their duties regardless of how much they operate (Greenhalgh \& Rosenblatt, 2010). This lack of an employer's commitments shows that the attitude and results of the staff are adversely affected (Ashill, Rod, \& Carruthers, 2008). This opinion shows that the equality in the return of relations between staff and workers shows the value of cultural return when staff works difficult or overtime and see the requirement of long term job security by their workers.

Based on personal swap reciprocity standards, employee allegiance and results are more probable to favor the organization (Conway \& Coyle-Shapiro, 2012). If companies menace staff with job insecurity or do not want to guarantee employment certainty where job requirements are strong, employee-worker relations will be under pressure and staff less inclined to operate difficult (i.e. to conduct faster) or only retain a strong enough standard of output to prevent redundancies. It has been demonstrated that the connection between return and cognitive results has been favorably affected by occupational safety (Loi, Chan, \& Lam, 2014). Furthermore, (Fried et al., 2003) noted that the beneficial relationship between position transparency and job performance was enhanced by job security. We therefore predict the connection between work requirements and results to be changed with job security. Ensure the establishment of equal exchange between workers and staff (Lu, Du, Xu, \& Zhang, 2017).

An employee-employee connection as a type of cultural exchange represents an employee's subjective faith in the contribution that they must provide and induce employer to make in return (X. Wang, Wang, Xu, \& Ji, 2014). In exchange, providing long-term job security is regarded to be one of the commitments on their workers (also called' inductions') (Anis et al., 2011). Their staff must be given a long-term work safety. So staffs think that their workers have achieved their commitments when they encounter work safety. Employees are encouraged to engage in and execute well in the interests of reciprocity (Jung \& Yoon, 2015). In comparison, the unreasonable connection between staff and workers may be seen as a small work safety perception (Keim et al., 2014) because staff feel that workers have not fulfilled their duties regardless of how much they operate. (Greenhalgh \& Rosenblatt, 2010). Such a breach of the commitments of a employer 
has a negative impact on job behavior and results of staff (Zhao, Wayne, Glibkowski, \& Bravo, 2007).

In this respect the equal exchange of relations between staff and workers is created, showing the high quality of personal exchanges if staff work difficult or overtime and perception that their employers are provided with long-term job security. Based on cultural transfer standards of reciprocity, staff is more inclined to profit their organization, with allegiance and excellent results (Conway \& Coyle-Shapiro, 2012). When organizations menace staff with job insecurity, or when requirements are big, they do not want to guarantee job security, they are threatened by employee-employer relationships and are less inclined to operate difficult (i.e. good performances), or to retain a standard of output strong enough to prevent the redundancies. Evidences have been found that the connection between swap performance and cognitive results has been strongly mitigated by work protection (Zaqout, 2016). (Fried et al., 2003) also discovered that safety at work has enhanced good relations between job demand and job performance.

\section{The Job Demands-Resources (JD-R) Model}

One of the systems used to describe employment and burnout is the Job-Devolution system ( $S$ Rothmann \& Jordaan, 2006). This system recommends that all occupations have their own distinctive well-being features and that these attributes can be modeled into two wide classifications, namely employment opportunities and labor requirements (Buys \& Rothmann, 2010; S Rothmann \& Jordaan, 2006). Employment funds include the physical, psychological, cultural and organizational elements of the job, which can help to reach work objectives, decrease employment requirements and boost personal growth and development. Employment requirements relate to the physical, mental and cultural or organizational elements of the work that are relentlessly related to physical and/or psychological power and certain physiological and/or psychological expenses (S Rothmann \& Jordaan, 2006).

Studies on work engagement by (Roodt \& Braine, 2011) The JD-R model confirms that employment engagement is predicted primarily when the demand for employment is high. (Mostert, Cronje, \& Pienaar, 2006) It was concluded that demand for jobs and assets are comprised of five variables including (2) overload, (2) insecurity in jobs, (3) development and development possibilities and (4) corporate assistance. The quantity of job, mental burden, and emotional burden is described as excess burden. Job insecurity relates to the insecurity at work today and in the future. A sufficient diversity is recognized as development possibilities, learning possibilities, and independence. Advancement means progress in an organization that involves pay, preparation and job possibilities. Supervisor connections, data provision, communication, involvement, colleague social support and contact possibilities in the organization are organizational help (Stander \& Rothmann, 2010). The Job-Development system is a proof of work-resources as the primary predictor of employment commitment and special work opportunities, for example personal assistance from fellow workers, consultative training, quality reviews and time regulate (Bakker, Demerouti, \& Schaufeli, 2003). Job requirements predicted emotions of depletion and absence of job assets lead to a disengagement from work, according to the JD-R model definition of burnout (Demerouti et al., 2001). The 2007 JD-R model of work 
involvement, according to (Demerouti et al., 2001) presumed that employer funds and personnel forecast work involvement autonomously or jointly. When demand for jobs is large, employment and staff funds have a good effect on commitment and a beneficial effect on job performance in turn. As such, committed staffs who perform well can build up their own funds that promote commitment over moment once more (Xanthopoulou et al., 2007).

\section{Theoretical Framework}

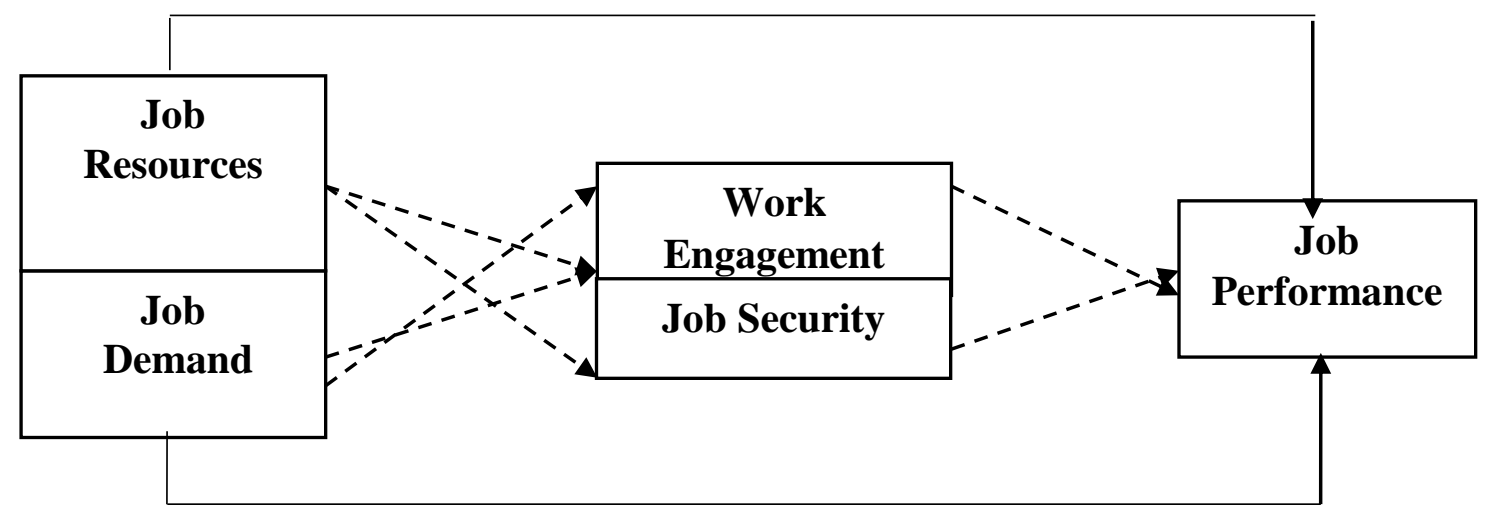

\section{Hypothesis}

$\mathbf{H}^{1}$ :- $\quad$ Job demand is negatively related to job performance.

$\mathbf{H}^{2}$ :- $\quad$ Job resources have a positive impact on job performance.

$\mathbf{H}^{\mathbf{3}}$ :- $\quad$ Work engagement and job security strongly mediates the relation between job demand and job performance.

$\mathbf{H}^{4}$ :- $\quad$ Both WE and JS positively mediate the relation between job resources and job performance.

\section{Methods}

\section{Procedure and Participants}

The information used in this study is fundamental in design. Data from local staff, Pakistan's first division executives, was gathered in the utilities industry. In which medical, education and hospitality were included. Data gathered both from the public and personal sectors. The organized questionnaire is a tool used for information compilation. The 5-point likert scale is used in all questions. This research uses the selected method of recording the questionnaire sent to both utilities and staff of the public industries. The suggested sample size consisted of 500 . However, 320 questionnaires were returned with a 64 percent response rate. Participants have a median era of $20-30$ years. $88 \%$ of the workers are in the medical sector, most of them have a master's and bachelor's degree.

\section{Scales and Questionnaire}

To measure job performance, three item scales adopted from (Goodman \& Svyantek, 1999). Five items scale were adopted from pervious study which is developed by (Spector \& Jex, 1998) to 
measure the job demand. Job resources were measure by using three item scales which were developed by (Bakker, Demerouti, Taris, Schaufeli, \& Schreurs, 2003). To measure Job security, there were five item scales that are adopted from (Wang, Lu, \& Lu, 2014). To measure work engagement, three items scale were utilized, and the scale is established by (Schaufeli et al., 2002). And the study used 5-point Likers scale ranging from 1-5 that shows that 1 for strongly disagreed and 5 for strongly agreed.

\section{Descriptive Statistics}

\begin{tabular}{|l|r|r|r|r|r|}
\hline \multicolumn{1}{|c|}{ Variables } & $\mathrm{N}$ & $\begin{array}{c}\text { Minimu } \\
\mathrm{m}\end{array}$ & Maximum & \multicolumn{1}{c|}{ Mean } & \multicolumn{1}{c|}{ Std. Deviation } \\
\hline Job Resources & 320 & 2.50 & 5.00 & 4.2747 & .49393 \\
\hline Job Demand & 320 & 1.40 & 5.00 & 4.0531 & .75736 \\
\hline Work Engagement & 320 & 2.00 & 5.00 & 4.1868 & .58957 \\
\hline Job Security & 320 & 2.64 & 5.00 & 4.4614 & .44455 \\
\hline Job Performance & 320 & 2.00 & 5.00 & 4.1953 & .55070 \\
\hline
\end{tabular}

Job Resources has Mean Value of 4.27 \& Standard Deviation of 0.49, Job Demand has Mean Value of 4.05 \& Standard Deviation of 0.75, Work Engagement (Intervening Variable) has Mean Value of 4.18 \& Standard Deviation of 0.58, Job Security (Intervening Variable) has Mean Value of 4.46 \& Standard Deviation of 0.44 and Job Performance has Mean Value of 4.19 \& Standard Deviation of 0.55 . In the above table $\mathrm{N}$ shows the total number of respondents which is 320 and minimum values of all variables (JR, JD, WE, JS and JP) is 2.50, 1.40, 2.00, 2.64 and 2.00 respectively while maximum values of all variables (JR, JD, WE, JS and JP) is 5.00 .

\section{Correlation Analysis}

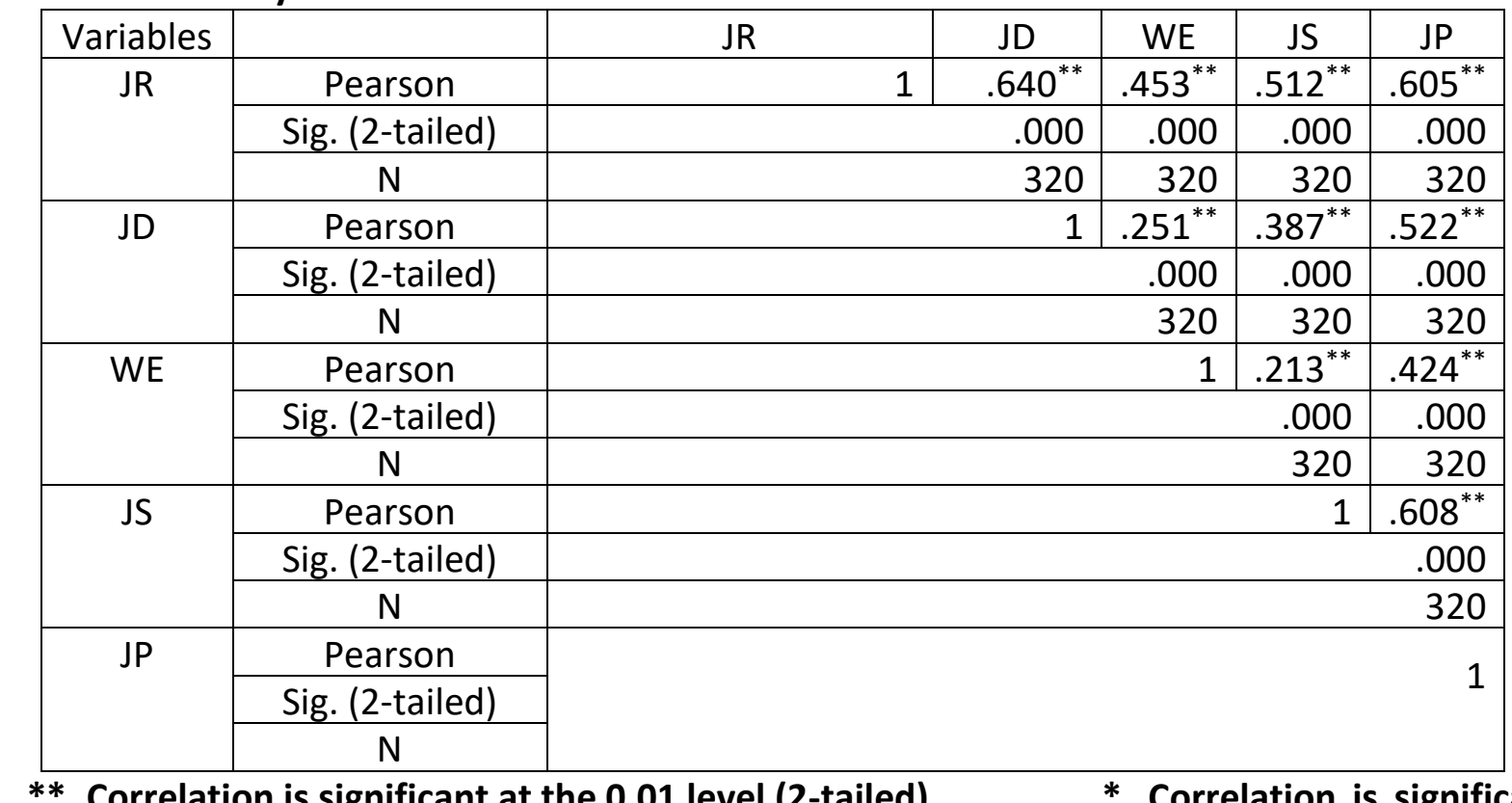

\footnotetext{
$* *$. Correlation is significant at the 0.01 level (2-tailed). at the 0.05 level (2-tailed).
} 
Correlation Table 2 shows the association between independent and depended variable so, the result of above table explain that job resources are significantly linked with job demand with .640 value, which is highly significant at $1 \%$. The table also indicates that job resources are significantly associates with all other variables with the value of $.453, .512$ and .605 . Job demand is positively related with job demand, work engagement, job security and job performance with the value of $.251, .387$, and .522. Furthermore, work engagement is also having a significant link with job security and job performance .213 and .424 , Lastly, job security is also having a significant link with job performance with the value of .608.

\section{Reliability Analysis}

\begin{tabular}{|c|c|c|c|c|c|}
\hline \multicolumn{6}{|c|}{ Reliability test (Cronbach's Alpha value) } \\
\hline $\begin{array}{c}\text { Cronbach' } \\
\text { s Alpha }\end{array}$ & Job Resources & Job Demand & Job Security & Work Engagement & JP \\
\cline { 2 - 6 } & .846 & .930 & .872 & .882 & .860 \\
\hline
\end{tabular}

According to the above Table of Cronbach's Alpha value of JR, JD , JS , WE and job performance is $.846, .930, .872, .882$ and .860 . The table shows the estimations of Cronbach's Alpha is more than 0.7 , it shows the reliability of data.

\section{Regression Analysis of Job Demand}

\begin{tabular}{|l|r|r|r|r|r|}
\hline \multicolumn{7}{|c|}{ Model Summary } \\
\hline Model & $\mathrm{R}$ & \multicolumn{1}{|c|}{ R Square } & $\begin{array}{c}\text { Adjusted R } \\
\text { Square }\end{array}$ & Std. Error & $\begin{array}{c}\text { Durbin- } \\
\text { Watson }\end{array}$ \\
\hline 1 & $.522^{\mathrm{a}}$ & .273 & .270 & .47043 & 2.250 \\
\hline 2 & $.726^{\mathrm{b}}$ & .528 & .523 & .38026 & \\
\hline
\end{tabular}

\begin{tabular}{|c|c|c|c|c|c|c|}
\hline \multicolumn{7}{|c|}{ Coefficients } \\
\hline \multirow{2}{*}{\multicolumn{2}{|c|}{ Model }} & \multicolumn{2}{|c|}{$\begin{array}{l}\text { Unstandardized } \\
\text { Coefficients }\end{array}$} & \multirow{2}{*}{$\begin{array}{c}\text { Standardized } \\
\text { Coefficients } \\
\text { Beta }\end{array}$} & \multirow[t]{2}{*}{$\mathrm{t}$} & \multirow[t]{2}{*}{ Sig. } \\
\hline & & $\mathrm{B}$ & Std. Error & & & \\
\hline \multirow[t]{2}{*}{1} & (Constant) & 2.657 & .143 & & 18.528 & .000 \\
\hline & JD & .380 & .035 & .522 & 10.915 & .000 \\
\hline \multirow[t]{4}{*}{2} & (Constant) & -.102 & .241 & & -.422 & .673 \\
\hline & $J D$ & .208 & .031 & .286 & 6.697 & .000 \\
\hline & WE & .241 & .038 & .258 & 6.402 & .000 \\
\hline & JS & .548 & .052 & .443 & 10.466 & .000 \\
\hline
\end{tabular}


Multiple Regression Analysis with Mediators

\begin{tabular}{|l|l|r|r|r|r|r|}
\hline \multicolumn{7}{|c|}{ ANOVA } \\
\hline \multicolumn{2}{|l|}{ Model } & Sum of Squares & df & \multicolumn{1}{c|}{$\begin{array}{c}\text { Mean } \\
\text { Square }\end{array}$} & F & Sig. \\
\hline \multirow{2}{*}{1} & Regression & 26.368 & 1 & 26.368 & 119.145 & $.000^{\mathrm{b}}$ \\
\cline { 2 - 7 } & Residual & 70.375 & 318 & .221 & & \\
\cline { 2 - 7 } & Total & 96.743 & 319 & & & \\
\hline \multirow{2}{*}{2} & Regression & 51.050 & 3 & 17.017 & 117.681 & $.000^{\mathrm{c}}$ \\
\cline { 2 - 7 } & Residual & 45.693 & 316 & .145 & & \\
\cline { 2 - 8 } & Total & 96.743 & 319 & & & \\
\hline
\end{tabular}

\section{Regression Analysis of Job Resources}

\begin{tabular}{|l|r|r|r|r|r|}
\hline \multicolumn{7}{|c|}{ Model Summary } \\
\hline \multicolumn{1}{|c|}{ Model } & R & R Square & Adjusted R & \multicolumn{1}{c|}{ Std. Error } & Durbin- \\
\hline 1 & $.605^{\mathrm{a}}$ & .366 & .364 & .43904 & 1.836 \\
\hline 2 & $.720^{\mathrm{b}}$ & .518 & .514 & .38406 & \\
\hline
\end{tabular}

\begin{tabular}{|c|c|c|c|c|c|c|}
\hline \multicolumn{7}{|c|}{ Coefficients } \\
\hline & \multirow{2}{*}{ Model } & \multicolumn{2}{|c|}{ Unstandardized Coefficients } & \multirow{2}{*}{$\begin{array}{c}\text { Standardized } \\
\text { Beta }\end{array}$} & \multirow{2}{*}{$\mathrm{t}$} & \multirow{2}{*}{ Sig. } \\
\hline & & $\mathrm{B}$ & Std. Error & & & \\
\hline \multirow[t]{2}{*}{1} & (Constant) & 1.310 & .214 & & 6.119 & .000 \\
\hline & $\mathrm{JR}$ & .675 & .050 & .605 & 13.560 & .000 \\
\hline \multirow[t]{4}{*}{2} & (Constant) & -.301 & .247 & & -1.216 & .225 \\
\hline & $\mathrm{JR}$ & .341 & .056 & .306 & 6.143 & .000 \\
\hline & WE & .185 & .041 & .198 & 4.527 & .000 \\
\hline & JS & .507 & .056 & .409 & 9.002 & .000 \\
\hline
\end{tabular}

Regression Analysis with mediators

\begin{tabular}{|c|c|c|c|c|c|c|}
\hline \multicolumn{7}{|c|}{ ANOVA } \\
\hline \multicolumn{2}{|r|}{ Model } & Sum of Squares & Df & Mean & $\mathrm{F}$ & Sig. \\
\hline \multirow[t]{3}{*}{1} & Regression & 35.446 & 1 & 35.446 & 183.887 & $.000^{b}$ \\
\hline & Residual & 61.297 & 318 & .193 & & \\
\hline & Total & 96.743 & 319 & & & \\
\hline \multirow[t]{3}{*}{2} & Regression & 50.131 & 3 & 16.710 & 113.288 & $.000^{c}$ \\
\hline & Residual & 46.612 & 316 & .148 & & \\
\hline & Total & 96.743 & 319 & & & \\
\hline
\end{tabular}

The above tables show that the job demand has a positive relation with job performance because the $p$-value is 0.000 which is lower than 0.05 means if the job demand is increase then the job performance is also increase. The value of $R$ square and adjusted $R$ square is .273 and .270. Durbin-Watson is calculated to examine the nature of the correlation between the variables which defines either relation are negative, zero or positive. 2.250 is the value of Durbin Watson, 
which is lower than 2.5 it means that there are significant relationships between the variables. Furthermore, the relation is more strong with the mediation effect of work engagement and job security between job demand and job performance with the significant level of .000 and mean square is 26.368 and 17.017 . The relation between job resources and job performance is also positive and highly significant with the $p$-value of 0.000 . And the value of $r$-square, adjust $r$-square and standard deviation is .366, .364 and .43904 value of Durbin-Watson is 1.863 which is also acceptable. The mediation effect of work engagement and job security is also having significant impact on job resources and job performance with the significant value of 0.000 and the value of mean square is 16.710 . So, the results show that the work engagement and job security is making the relation stronger between job resources and job performance.

\section{Hypothesis Testing}

\begin{tabular}{|c|c|c|}
\hline Hypothesis & Path & Results \\
\hline $\mathrm{H} 1$ & $\mathrm{JD}>\mathrm{JP}$ & Un-Supported \\
\hline $\mathrm{H} 2$ & $\mathrm{JR}>\mathrm{JP}$ & Supported \\
\hline $\mathrm{H} 3$ & $\mathrm{JR}>\mathrm{WE}, \mathrm{JS}>\mathrm{JP}$ & Supported \\
\hline $\mathrm{H} 4$ & $\mathrm{JD}>\mathrm{WE}, \mathrm{JS}>\mathrm{JP}$ & Supported \\
\hline
\end{tabular}

\section{Conclusion and Recommendation}

After the study, we reached to the conclusion that there are optimistic significant relationships between in depended variable which is job demand and job resources and depended variable job performance and mediating variable work engagement and job security also have the strong impact on job resources, job demand and job performance. If the job demand and job resources are high, then the job performance is also high and work engagement and job security also plays a positive role between both of these variables. In the research they do, (Rothmann \& Jordaan, 2006) argues that people can use their own degree, body, emotional and cognitive.

According to (Rhoades \& Eisenberger, 2002), job protection "is expected to provide a strong indication of POS, especially when downsizing is prevalent in recent years" There are several empirical references to the current study. We first moved beyond typically literary stress frameworks (for example, (Beehr, Jex, Stacy, \& Murray, 2000; Rosen et al., 2010) by adopting a social exchange perspective, and shed light on the combined results, identifying an important boundary condition between job demand and employment performance. Cross-sample results from studies with various concepts and measures consistently showed that job security altered the relationship between job demand and job performance in order to improve work performance, although not significantly, for the employees as a result of increased work safety but reduced performance with lower job security. No study examined workplace protection as a boundary condition in our understanding, through the social exchange system prism, for the relation between job demand and work performance. The viewpoint of mutual interaction allows one therefore to consider from a different perspective the essence of job demands and job performance. Secondly, our research has strengthened the awareness of ambiguous situations about employee-employer ties. Working security as an opportunity in the competitive labor market today has important significance (Fairlie, 2011; Keim et al., 2014), In particular, (Wang, Lu, \& Siu, 2015), when occupational safety (i.e., job insecurity) is not provided, people with poor 
social security networking countries (Debus, Probst, Konig, \& Kleinmann, 2012) can be more stressful or harmful. There is therefore a growing need for employee safety in the existing workplace (Keim et al., 2014) to be a critical form of employer inductive measures; on the other hand, employees have to fulfill a duty to perform difficult tasks. Requirements, especially when organizations endure hardship during economic recessions, by contributing their time and effort in exchange relations (Eisenberger, Armeli, Rexwinkel, Lynch, \& Rhoades, 2001).

Employees who engage in their tasks are therefore physically involved, cognitively aware and associated with others in the context of their jobs. In the work they do feel valued and valuable by the emotional meaning of workers, and the relation between their expectations and their job fitness produces inter-personal interactions with colleagues (Rothmann \& Olivier, 2007).

In addition, workers who have a sense of emotional security in their working environments without fearing adverse impacts and who value and maintain relationships with their colleagues and superintendents and versatile behavioral expectations (S Rothmann \& Jordaan, 2006). Workplace health and the good relationships between employees and managers are therefore two key contributors to a higher level of employee engagement within an organization. This helps you to express your values and beliefs in your working environment further (Shamir, 1991).

In addition, organizations must ensure that they provide their workers with the physical, emotional and psychological resources needed to encourage the involvement of their 79 employees (Rothmann \& Olivier, 2007). This would have a positive impact on the ability of workers to be better prepared and able to play their work and to be burnout-free. Employees of businesses are likely to experience burnout as work stress is chronic if the availability of jobs exceeds high demands (Rothmann, 2008; Rothmann \& Malan, 2011).

The first symptom of burnout syndrome may be a condition of emotional exhaustion and the lack of energy and emaciation. Organizations may interfere by improving the access to employment opportunities, namely by providing subordinate input, providing room for personal development and co-worker support and taking part in decision making processes, all of them showing positive effects on the participation in work (van den Berg et al., 2008). Consequently, the company is encouraged to concentrate on employee capital so that its level of commitment is increased. In terms of the relationship workers have with their supervisors, the consistency of explanations of their roles input they obtain in terms of improving work performance and the degree of involvement they are allowed to take part in the decision-making process would be helpful in the beginning of this process (Sebastiaan Rothmann \& Coetzer, 2003).

Organizations may make their workers less stressed in the working environment by strategic organizational approaches to the challenges (Steyn Rothmann, Steyn, \& Mostert, 2005). Training and development programmers should be introduced to provide workers with stress management techniques. Another productive initiative for organizations can be performed to establish or re-deploy jobs that can improve the autonomy and freedom of middle managers as well as worker managers, which can provide more incentives for workers to participate (A. B. Bakker \& Leiter, 2010). 


\section{Limitation and Future Implication}

A potential drawback to this study might be that respondents have not been frank about answering the questions because they were concerned about their work environment being compromised or abused. Nevertheless, a summary of the method of research process in the informed consent form has addressed the issue of privacy. The participants were informed that their identity would remain anonymous.

The sampling method may have been appropriate but elements of bias could have been introduced by the survey participants. The stronger results might have been increased by a higher return on results from the online questionnaire. A low response rate could have been contributed by the method (e-mailing Web-based questionnaires).

The effect of personal resources such as resilience, control locus, self-efficiency, motivation and self-esteem should be examined in future research on job involvement. The theories discussed earlier in this study also suggest that different factors increase the level of involvement of individuals depending on their individual circumstances, such as the organization level.

Factors that increase or decrease the degree of employees ' involvement can therefore differ from person to person and the use of different personal resources by individuals while facing high demands for work (Xanthopoulou et al., 2007).

In addition, future research could include a qualitative approach in a quantitative context (Khan, Fatima, \& Matloob, 2019). Qualitative interviews can lead to a better understanding and observation of various people. Job strain can also use as a mediator in the place of work engagement and work engagement can be used as depended variable and job performance can use as in-depended variable.

\section{References}

Ahammad, M. F., Tarba, S. Y., Liu, Y., \& Glaister, K. W. (2016). Knowledge transfer and crossborder acquisition performance: The impact of cultural distance and employee retention. International Business Review, 25(1), 66-75.

Anis, A., Nasir, A., \& Safwan, N. (2011). Employee retention relationship to training and development: A compensation perspective. African Journal of Business Management, 5(7), 2679.

Ashill, N. J., Rod, M., \& Carruthers, J. (2008). The effect of management commitment to service quality on frontline employees' job attitudes, turnover intentions and service recovery performance in a new public management context. Journal of Strategic Marketing, 16(5), 437-462.

Bakker, A., Demerouti, E., \& Schaufeli, W. (2003). Dual processes at work in a call centre: An application of the job demands-resources model. European Journal of work and organizational psychology, 12(4), 393-417.

Bakker, A. B., \& Demerouti, E. (2008). Towards a model of work engagement. Career development international, 13(3), 209-223.

Bakker, A. B., Demerouti, E., Taris, T. W., Schaufeli, W. B., \& Schreurs, P. J. (2003). A multigroup analysis of the job demands-resources model in four home care organizations. International Journal of Stress Management, 10(1), 16. 
INTERNATIONAL JOURNAL OF ACADEMIC RESEARCH IN BUSINESS AND SOCIAL SCIENCES

Vol. 9, No. 11, November, 2019, E-ISSN: 2222-6990 @ 2019 HRMARS

Bakker, A. B., \& Leiter, M. P. (2010). Work engagement: A handbook of essential theory and research: Psychology press.

Beehr, T. A., Jex, S. M., Stacy, B. A., \& Murray, M. A. (2000). Work stressors and coworker support as predictors of individual strain and job performance. Journal of organizational behavior, 21(4), 391-405.

Blau, P. (1964). Exchange and power in social life Wiley New York.

Braine, R. D., \& Roodt, G. (2011). The Job Demands-Resources model as predictor of work identity and work engagement: A comparative analysis. SA Journal of Industrial Psychology, 37(2), 52-62.

Buys, C., \& Rothmann, S. (2010). Burnout and engagement of reformed church ministers. SA Journal of Industrial Psychology, 36(1), 1-11.

Conway, N., \& Coyle-Shapiro, J. A. M. (2012). The reciprocal relationship between psychological contract fulfilment and employee performance and the moderating role of perceived organizational support and tenure. Journal of occupational and Organizational Psychology, 85(2), 277-299.

Coyle-Shapiro, J. A., \& Shore, L. M. (2007). The employee-organization relationship: Where do we go from here? Human resource management review, 17(2), 166-179.

Debus, M. E., Probst, T. M., König, C. J., \& Kleinmann, M. (2012). Catch me if I fall! Enacted uncertainty avoidance and the social safety net as country-level moderators in the job insecurity-job attitudes link. Journal of Applied psychology, 97(3), 690.

Demerouti, E., Bakker, A. B., Nachreiner, F., \& Schaufeli, W. B. (2001). The job demands-resources model of burnout. Journal of Applied psychology, 86(3), 499.

Eisenberger, R., Armeli, S., Rexwinkel, B., Lynch, P. D., \& Rhoades, L. (2001). Reciprocation of perceived organizational support. Journal of Applied psychology, 86(1), 42.

Fairlie, P. (2011). Meaningful work, employee engagement, and other key employee outcomes: Implications for human resource development. Advances in Developing Human Resources, 13(4), 508-525.

Fried, Y., Shirom, A., Gilboa, S., \& Cooper, C. L. (2008). The mediating effects of job satisfaction and propensity to leave on role stress-job performance relationships: Combining metaanalysis and structural equation modeling. International Journal of Stress Management, 15(4), 305.

Fried, Y., Slowik, L. H., Shperling, Z., Franz, C., Ben-David, H. A., Avital, N., \& Yeverechyahu, U. (2003). The moderating effect of job security on the relation between role clarity and job performance: A longitudinal field study. Human Relations, 56(7), 787-805.

Glaser, D. N., Tatum, B. C., Nebeker, D. M., Sorenson, R. C., \& Aiello, J. R. (1999). Workload and social support: Effects on performance and stress. Human Performance, 12(2), 155-176.

Goodman, S. A., \& Svyantek, D. J. (1999). Person-organization fit and contextual performance: Do shared values matter. Journal of Vocational Behavior, 55(2), 254-275.

Greenhalgh, L., \& Rosenblatt, Z. (2010). Evolution of research on job insecurity. International Studies of Management \& Organization, 40(1), 6-19. 
INTERNATIONAL JOURNAL OF ACADEMIC RESEARCH IN BUSINESS AND SOCIAL SCIENCES

Vol. 9, No. 11, November, 2019, E-ISSN: 2222-6990 @ 2019 HRMARS

Johnson, S., Cooper, C., Cartwright, S., Donald, I., Taylor, P., \& Millet, C. (2005). The experience of work-related stress across occupations. Journal of managerial psychology, 20(2), 178187.

Jung, H. S., \& Yoon, H. H. (2015). Understanding pay satisfaction: The impacts of pay satisfaction on employees' job engagement and withdrawal in deluxe hotel. International Journal of Hospitality Management, 48, 22-26.

Keim, A. C., Landis, R. S., Pierce, C. A., \& Earnest, D. R. (2014). Why do employees worry about their jobs? A meta-analytic review of predictors of job insecurity. Journal of occupational health psychology, 19(3), 269.

Khan, M. A. H., Fatima, A., \& Matloob, A. (2019). The Effect of Social Media Marketing In Online Fashion Apparel with the Mediating Role of Fashion Consciousness, Brand Consciousness and Value Consciousness. International Journal of Recent Innovations in Academic Research, 3(9), 65-83.

Kraimer, M. L., Wayne, S. J., Liden, R. C., \& Sparrowe, R. T. (2005). The role of job security in understanding the relationship between employees' perceptions of temporary workers and employees' performance. Journal of Applied psychology, 90(2), 389.

Kuo, T. H., Ho, L. A., Wu, Y. J., \& Lin, C. T. (2010). The factors influencing employees' attitudes in high-tech environment. Industrial Management \& Data Systems, 110(7), 1054-1072.

Loi, R., Chan, K. W., \& Lam, L. W. (2014). Leader-member exchange, organizational identification, and job satisfaction: A social identity perspective. Journal of occupational and Organizational Psychology, 87(1), 42-61.

Lu, C. Q., Du, D. Y., Xu, X. M., \& Zhang, R. F. (2017). Revisiting the relationship between job demands and job performance: The effects of job security and traditionality. Journal of occupational and Organizational Psychology, 90(1), 28-50.

Mostert, K., Cronje, S., \& Pienaar, J. (2006). Job resources, work engagement and the mediating role of positive work-home interaction of police officers in the North West Province. Acta Criminologica: Southern African Journal of Criminology, 19(3), 64-87.

$\mathrm{Ng}, \mathrm{T}$. W. (2015). The incremental validity of organizational commitment, organizational trust, and organizational identification. Journal of Vocational Behavior, 88, 154-163.

Rhoades, L., \& Eisenberger, R. (2002). Perceived organizational support: a review of the literature. Journal of Applied psychology, 87(4), 698.

Rhoades, L., Eisenberger, R., \& Armeli, S. (2001). Affective commitment to the organization: The contribution of perceived organizational support. Journal of Applied psychology, 86(5), 825.

Roodt, G., \& Braine, D. R. (2011). The job demands-resources model as predictor of work identity and work engagement: A comparative analysis. SA Journal of Industrial Psychology, 37(2), 1-11.

Rosen, C. C., Chang, C. H., Djurdjevic, E., \& Eatough, E. (2010). Occupational stressors and job performance: An updated review and recommendations New developments in theoretical and conceptual approaches to job stress (pp. 1-60): Emerald Group Publishing Limited.

Rothmann, S. (2008). Job satisfaction, occupational stress, burnout and work engagement as components of work-related wellbeing. SA Journal of Industrial Psychology, 34(3), 11-16. 
Rothmann, S., \& Coetzer, E. P. (2003). The big five personality dimensions and job performance. SA Journal of Industrial Psychology, 29(1), 68-74.

Rothmann, S., \& Jordaan, G. (2006). Job demands, job resources and work engagement of academic staff in South African higher education institutions. SA Journal of Industrial Psychology, 32(4), 87-96.

Rothmann, S., \& Malan, M. (2011). Work-related well-being of South African hospital pharmacists. SA Journal of Industrial Psychology, 37(1), 1-11.

Rothmann, S., \& Olivier, A. (2007). Antecedents of work engagement in a multinational company. SA Journal of Industrial Psychology, 33(3), 49-56.

Rothmann, S., Steyn, L., \& Mostert, K. (2005). Job stress, sense of coherence and work wellness in an electricity supply organisation. South African Journal of Business Management, 36(1), 55-63.

Rousseau, D. M. (1990). New hire perceptions of their own and their employer's obligations: A study of psychological contracts. Journal of organizational behavior, 11(5), 389-400.

Saks, A. M. (2006). Antecedents and consequences of employee engagement. Journal of managerial psychology, 21(7), 600-619.

Schaufeli, W. B., Salanova, M., Gonzalez-Roma, V., \& Bakker, A. B. (2002). The measurement of engagement and burnout: A two sample confirmatory factor analytic approach. Journal of Happiness studies, 3(1), 71-92.

Shamir, B. (1991). Meaning, self and motivation in organizations. Organization studies, 12(3), 405-424.

Shaw, J. D., Dineen, B. R., Fang, R., \& Vellella, R. F. (2009). Employee-organization exchange relationships, HRM practices, and quit rates of good and poor performers. Academy of Management Journal, 52(5), 1016-1033.

Shore, L. M., Tetrick, L. E., Taylor, M. S., Shapiro, C. J. A. M., Liden, R. C., McLean Parks, J., . . . Roehling, M. V. (2004). The employee-organization relationship: A timely concept in a period of transition Research in personnel and human resources management (pp. 291370): Emerald Group Publishing Limited.

Spector, P. E., \& Jex, S. M. (1998). Development of four self-report measures of job stressors and strain: interpersonal conflict at work scale, organizational constraints scale, quantitative workload inventory, and physical symptoms inventory. Journal of occupational health psychology, 3(4), 356.

Stander, M. W., \& Rothmann, S. (2010). Psychological empowerment, job insecurity and employee engagement. SA Journal of Industrial Psychology, 36(1), 1-8.

Voorde, V. D. K., Veld, M., \& Veldhoven, V. M. (2016). Connecting empowerment-focused HRM and labour productivity to work engagement: the mediating role of job demands and resources. Human Resource Management Journal, 26(2), 192-210.

Berg, V. D. T. I., Alavinia, S., Bredt, F. J., Lindeboom, D., Elders, L. A., \& Burdorf, A. (2008). The influence of psychosocial factors at work and life style on health and work ability among professional workers. International archives of occupational and environmental health, 81(8), 1029-1036. 
Wang, H. J., Lu, C. Q., \& Lu, L. (2014). Do people with traditional values suffer more from job insecurity? The moderating effects of traditionality. European Journal of work and organizational psychology, 23(1), 107-117.

Wang, H. J., Lu, C. Q., \& Siu, O. I. (2015). Job insecurity and job performance: The moderating role of organizational justice and the mediating role of work engagement. Journal of Applied psychology, 100(4), 1249.

Wang, W., Arora, R., Livescu, K., \& Bilmes, J. (2015). On deep multi-view representation learning. Paper presented at the International Conference on Machine Learning.

Wang, X., Wang, L., Xu, X., \& Ji, P. (2014). Identifying employee turnover risks using modified quality function deployment. Systems Research and Behavioral Science, 31(3), 398-404.

Woods, S. A., \& Sofat, J. A. (2013). Personality and engagement at work: The mediating role of psychological meaningfulness. Journal of Applied Social Psychology, 43(11), 2203-2210.

Xanthopoulou, D., Bakker, A. B., Dollard, M. F., Demerouti, E., Schaufeli, W. B., Taris, T. W., \& Schreurs, P. J. (2007). When do job demands particularly predict burnout? The moderating role of job resources. Journal of managerial psychology, 22(8), 766-786.

Zaqout, E. M. (2016). leadership competencies of middle managers at palestinian media enterprises and its impact on employees job performance: case study al-aqsa satellite tv channel. leadership competencies of middle managers at palestinian media enterprises and its impact on employees job performance: case study al-aqsa satellite tv channel.

Zhang, Y., LePine, J. A., Buckman, B. R., \& Wei, F. (2014). It's not fair... or is it? The role of justice and leadership in explaining work stressor-job performance relationships. Academy of Management Journal, 57(3), 675-697.

Zhao, H., Wayne, S. J., Glibkowski, B. C., \& Bravo, J. (2007). The impact of psychological contract breach on work-related outcomes: a meta-analysis. Personnel psychology, 60(3), 647-680. 